\title{
Varroa-specific hygienic behavior of Apis mellifera scutellata in Kenya
}

\author{
Sammy Kiprotich Cheruiyot ${ }^{1,2}$, H. Michael G. LattorfF ${ }^{1,3,4}$, Ruth Kahuthia-Gathu ${ }^{2}$, \\ Jenard Patrick MBugi ${ }^{2}$, Elliud Muli ${ }^{1}$ \\ ${ }^{1}$ International Centre of Insect Physiology and Ecology (ICIPE), P.O. Box 30772-00100, Nairobi, Kenya \\ ${ }^{2}$ School of Pure and Applied Sciences, Kenyatta University, P.O. Box 43844-00100, Nairobi, Kenya \\ ${ }^{3}$ German Centre for Integrative Biodiversity Research (iDiv) Halle-Jena-Leipzig, Deutscher Platz 5e, 04103, Leipzig, \\ Germany \\ ${ }^{4}$ Institut für Biologie, Martin-Luther-Universität Halle-Wittenberg, 06099, Halle (Saale), Germany
}

Received 1 May 2017 - Revised 16 December 2017 - Accepted 20 February 2018

\begin{abstract}
Varroa -specific hygienic behavior is a hereditary trait of honey bee (Apis mellifera), which supports resistance to Varroa destructor. This study investigated the response of Apis mellifera scutellata to Varroa -infested worker brood cells in Kenya, East Africa. Uncapping, removal of the brood, and disappearance of the introduced mite were recorded in a total of 690 cells into which live mites were introduced. We recorded a high proportion of untouched cells in controls (median, 80\%) compared to manipulated cells in which mites had been introduced (median, $12.5 \%$ ) with a significant difference (GLMM, $p<0.001$ ). Mites were removed and cells were recapped in about $26 \%$ of the artificially infested brood cells. When ten, eight, and five mites were singly introduced in closely neighboring brood cells, hygienic bees were more responsive in the high mite density regime of eight and ten mites, an indication of a possibility that chemicals play a role in identification of Varroa -infested brood cells.
\end{abstract}

\section{Apis mellifera scutellata / artificially infested brood cells / Varroa -specific hygienic behavior}

\section{INTRODUCTION}

Bee keeping globally has shown a significant trend of colony increase of more than $60 \%$ over the past 50 years from 1961 to 2013 (Moritz and Erler 2016). However, localized colony losses have been reported in some countries, especially on the Northern hemisphere (Neumann and Carreck 2010), contributed majorly by global honey trade and societal transition (Aizen and Harder 2009; Moritz and Erler 2016) among other factors such

Electronic supplementary material The online version of this article (https://doi.org/10.1007/s13592-018-0570-6) contains supplementary material, which is available to authorized users.

Corresponding author: S. Cheruiyot, cherusammy@gmail.com

Handling editor: Peter Rosenkranz as pathogens, pests, diseases, pesticides, and climate change, which have substantially contributed to the losses of honey bee colonies (Vanengelsdorp et al. 2008; Potts et al. 2010).

The hemophagous honey bee mite Varroa destructor is considered one of the major ectoparasites of honey bees of great economic importance to beekeepers (Neumann and Carreck 2010; Rosenkranz et al. 2010). Especially, the association of the mite with viruses and their transmission to bees are crucial factors causing harm to bees (Martin et al. 2012; Wilfert et al. 2016). V. destructor is a host-specific parasite whose growth and development entirely depends on honey bee brood to reproduce (Rosenkranz et al. 2010). Varroa mites enter cells with developing brood, where they suck hemolymph, which is a pre-requisite for developing ovaries (Garedew et al. 2004). Approximately $70 \mathrm{~h}$ after the cell 
capping, the first egg is laid (Ifantidis 1983) and the mites produce offspring, which will engage in brother-sister mating in fecal accumulation site (Donze et al. 1996), while the cell is still capped.

Different behavioral mechanisms acting to reduce Varroa destructor infestation in honey bees have been identified (Boecking and Spivak 1999; Nganso et al. 2017). Reduced mite reproductive success has been observed in several honey bee populations exposed to natural selection for survival under heavy mite infestation rates (Locke 2016). The best studied population is a population on Gotland, Sweden, for which the genetic basis of this adaptation has been studied as well (Lattorff et al. 2015; Locke 2016).

Another mechanism to reduce mite population growth is hygienic behavior. Counter attack behavioral mechanisms against brood diseases are known for a long time and are based on uncapping and removing behavior performed by individual hygienic bees (Arathi et al. 2000; Xonis et al. 2015). First detected for bees infected with American foulbrood, it has been proposed to be based on a two-locus genetic model with one locus for uncapping the brood and one locus responsible for removing diseased brood (Rothenbuhler 1964). However, this model has been challenged to be based at least on three loci (Moritz 1988) and by a QTL mapping study identifying at least six distinct genes (Oxley et al. 2010).

Varroa -specific hygienic (VSH) behavior acts to reduce the negative effects of this ectoparasitic mite (Evans and Spivak 2010). VSH behavior is the refined ability of honey bees to detect, uncap, and remove mite-infested brood leading to high mite infertility (Harbo and Harris 2005; Ibrahim and Spivak 2006). It is a heritable and highly variable trait which has been used in programs to breed strain of honey bees of European origin, resulting in diverse honey bee populations that are desirable for bee keeping (Guerra Jr. et al. 2000; Vandame et al. 2002; Ibrahim and Spivak 2006; Harris 2007). Hygienic bees remove affected brood most likely by detecting odor cues emanating from infested hosts, when these cues exceed the response threshold of the bees within the colony (Masterman et al. 2001; Martin et al. 2002). Indeed, the transcriptional response in antennal-specific genes suggests a key role for chemical discrimination of mite infested cells (Mondet et al. 2015). A detailed description of chemicals involved in the interaction between mites and honey bees has been given by Nazzi and Le Conte (2016). The VSH trait interferes with mite reproduction (Villa et al. 2009) as Varroa-specific hygienic reactions involves repeated uncapping and recapping of mite infested brood cells (Aumeier et al. 2000; Arathi et al. 2006; Harris 2007), leading to limited mite population growth, prolonged phoresy or even the death of the mites (Moritz 1985; Fries et al. 1994; Harris et al. 2010; Rosenkranz et al. 2010). These hygienic reactions towards Varroa destructor in capped brood cells can contribute to the colony's resistance (Boecking and Spivak 1999; Aumeier and Rosenkranz 2001). Resistance in the original host, Apis cerana (Eastern honey bee), has been reported to be due to limited reproduction of the mite on this honey bee species and behavioral mechanisms of defense that involves grooming and hygienic behaviors' (Peng et al. 1987). PaulPage et al. 2016 also documented that development of $V$. destructor is delayed in $A$. cerana as compared to $A$. mellifera due to higher susceptibility of mite-infested brood of the original host which leads to more efficient hygienic behavior, thereby providing a basis for honey bee colony survival to parasitism. Damage to these honey bee colonies is rarely experienced since a stable hostparasite relationship has been established (Rath 1999). Nganso et al. (2017) reported that hygienic and grooming behaviors' are better expressed in A. $m$. scutellata than those in A. mellifera hybrids of European origin. Furthermore, in spite of hosting most parasites, A. m . scutellata colonies appear healthier (Strauss et al. 2013). African honey bees also have more developed removal behavior to pin-killed brood as compared to Africanized bees (Fries and Raina 2003), a factor which may be contributing to its greater mite tolerance (Frazier et al. 2009). A. m. scutellata is known to exhibit general hygienic behavior, but its Varroa-specific hygienic behavior has not been investigated. East African population of $A . m$. scutellata has been reported to survive Varroa mite parasitism, requiring no chemical treatment even when coexisting with other pathogens responsible for the losses of colonies in Europe 
and North America (Frazier et al. 2009; Muli et al. 2014). It is unknown whether resistance (the ability to limit the fitness of the mite) in $A . m$. scutellata honey bees is associated with VSH behavior or other resistant mechanisms such as suppression of mite reproductive success and/or lower viral prevalence within African honey bee colonies. In this paper, we report the first results of investigations regarding the response of $A . m$. scutellata colonies to worker brood cells artificially infested with Varroa mites. The hypothesis of this study was that African honey bees would highly express VSH trait as it has been reported to be resistant to $V$. destructor.

\section{MATERIALS AND METHODS}

\subsection{Establishment of honey bee colonies}

The research study was conducted using 20 colonies of African bees (Apis mellifera scutellata), headed by naturally mated queens from the experimental apiary of the International Centre of Insect Physiology and Ecology (ICIPE) located in Karura forest $\left(1.23442^{\circ} \mathrm{S} ; 36.8347^{\circ} \mathrm{E}\right)$, Nairobi county, Kenya, between the period of June and September 2016. Colonies were housed in standard Langstroth hives containing eight-ten brood combs and were placed on stands protected by oil-filled cans to prevent ants from climbing and entering the hives and causing absconding of bees (Kinati et al. 2012). Sugar roll assay was done to obtain mites that were used for artificial infestation (Macedo et al. 2002; Dietemann et al. 2013).

\subsection{Hygienic behavior of Apis mellifera scutellata to pin-killed brood}

We screened 20 randomly selected colonies in the apiary using pin-killing brood assay, a common assay used to elicit hygienic behavior (Newton and Ostasiewski 1986; Palacio et al. 2010) to identify ten colonies that express high levels of general hygienic behavior (Fig. S1). Sugar roll assay was also done in these colonies to quantify the number of mites and correlated with general hygienic behavior (Fig. S2). Artificial killing of the brood to measure general hygienic behavior (GHB) response is an indication of the willingness of the colony to remove miteinfested brood (Boecking and Spivak 1999). A brood frame containing capped worker brood was selected and removed from each colony, bees shaken off and a few cells were uncapped to confirm the developmental stage (purple-eyed pupae). Each brood frame was placed on a flat surface and an open-ended PVC tube $(7.62 \mathrm{~cm}$ in diameter) was pressed into a frame containing purple-eyed pupae; this area corresponds to approximately 207 cells of naturally drawn African honey bee comb (Muli et al. 2014). The brood cells were then pin killed using a sterilized needle and each brood frame was returned into its colony. After 24 h, GHB of a colony was calculated as follows:

$$
\% \mathrm{GHB}=\left(\frac{N_{\text {rem }}}{N_{\text {tot }}-N_{\text {uncap }}}\right) \times 100
$$

with $N_{\text {rem }}$, number of fully and/or partially removed pupae; $N_{\text {tot }}$, total number of cells (in $A$. $m$. scutellata, this corresponds to 207); and $N$ uncap, number of originally uncapped or emptied cells.

Ten colonies that removed more than $85 \%$ of the pin-killed worker brood were considered to show high levels of general hygienic behavior (Gramacho and Goncalves 2009; Pereira et al. 2013) and hence, were used to evaluate Varroaspecific hygienic behavior.

\subsection{Varroa-specific hygienic behavior of Apis mellifera scutellata}

Varroa -specific hygienic behavior was determined using the method of Aumeier et al. (2000). The experiment was designed to detect VSH behavior in non-reproducing mites introduced in patches of closely neighboring brood cells. Frames containing worker brood cells with eggs were identified in each hygienic colony, marked, and followed up until capping. A frame of worker brood cells, $24 \mathrm{~h}$ after cell capping, was removed from each of the ten hygienic colonies. Worker brood cells were opened at one edge using solvent (ethanol)-washed forceps. Female phoretic mites were carefully introduced into the brood cells using a tip of a sterilized needle. All target mites 
were placed on the ventral side of the prepupa without harming the host and the cells were recapped with a drop of melted beeswax. On each experimental day, ten closely neighboring brood cells were singly introduced with one mite in the first colony, eight mites singly introduced in the second colony, and five mites singly introduced into the third colony. The same procedure was repeated for the other remaining seven colonies. At the end of the study period, each colony had been singly introduced with a total of 69 live mites (Tab. S1). Six hundred and ninety control cells (69 brood cells per colony) were sham manipulated (opened and recapped without inserting mites) on the other side of the same brood frame where the mites were introduced. Immediately after handling, combs were returned into their original colonies. Cells were marked and identified by using a transparent plastic sheet for subsequent recording of the number of brood cells that were emptied by the bees. Seventy-two hours later, the manipulated cells were carefully examined and recorded as follows: untouched cells (UC), cell cap opened (or partially opened) (CO), brood and mite removed (BR), and introduced mite removed but brood still present and recapped (MR). Untouched capped brood cells were carefully examined to verify the presence of the introduced mites.

\subsection{Statistical analysis}

We used Generalized Linear Mixed Effects Models (GLMM) along with the logit link function to account for non-normal distribution of the data for analysis of effects of the insertion of mites' vs the control, the effect of the category of Varroa-specific hygienic behavior and the number of mites introduced and for the effect of the number of mites introduced and the time point of manipulation within each of the categories of Varroa-specific hygienic behavior. Colony was used as a random factor in each of the models. The response variable was the percentage of cells within a category of a specific hygienic behavior. For the comparison treatment vs control, we used the category UC only, while for all other comparisons, all categories were used (UC, $\mathrm{CO}, \mathrm{BR}$, MR). We set-up a null model, which was tested against the full model using an ANOVA and the
Akaike Information Criterion (AIC). When the full model was significantly different from the null model and had a higher explanatory power $(\triangle \mathrm{AIC}$ of $>2)$, we used stepwise removal of interactions or factors as model simplification. Simplified models were tested against former, more complex models by means of an ANOVA and AIC. For all statistical tests, we used R version 3.3.1 ( $\mathrm{R}$ Core Team 2016). More detailed description of statistical methodology is given in the supplementary material.

\section{RESULTS}

Artificial introduction of mites provoked Varroa-specific hygienic behavior in Apis mellifera scutellata at varying frequencies. Apis mellifera scutellata worker bees responded highly to manipulated brood cells artificially infested with mites as compared to control cells (GLMM, $p<0.001)$. The percentage of untouched cells was high in controls (median, $80 \%$, first quartile $80 \%$, third quartile $90 \%$ ) and significantly different from treatments where mites had been introduced (median, $12.5 \%$, first quartile $0 \%$, third quartile $40 \%$ ) (Figure 1). We observed four categories of behavior, of which three represent typical hygienic behavior. The categories untouched cells (UC), cell caps opened (CO), brood removed (BR), and mite removed and cell recapped (MR) showed a significant interaction effect with the number of mites introduced (GLMM, behavior category $\times$ number of mites, $p>0.001)$. When categories were arranged according to their relationship to classical categories of Varroa-specific hygienic behavior, uncapping (CO, BR, MR) and removing (BR, $\mathrm{MR}$ ), their expression showed a dependency on the number of mites introduced. Five mites singly introduced into closely neighboring cells evoked less uncapping and less removing.

As there is no way to determine single effects under a significant interaction term in complexgeneralized linear models when used with link functions, we studied all behavioral categories (UC, CO, BR, MR) separately (Figure 2). There was no significant effect of time of mite introduction; however, there was a significant effect of the number of mites. The percentage of untouched cells, when singly infested with five, eight, or 


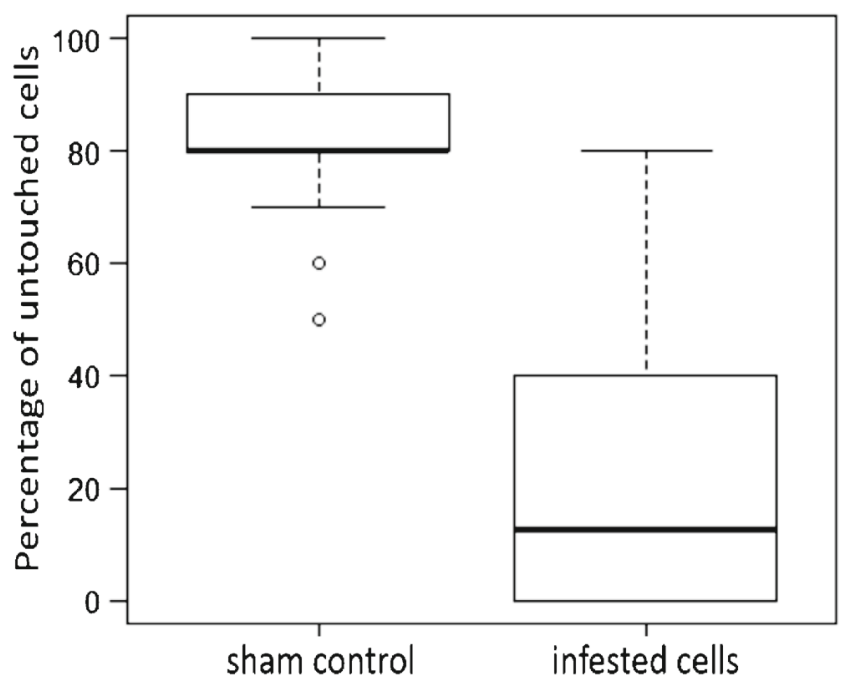

Control cells and Infested cells

Figure 1. Percentage of untouched cells by Apis mellifera scutellata in manipulated cells artificially infested with mites $(n=110)$ and controls $(n=579)$. Shown is the median (line), first and third quartile (box), first and third incl. 1.5 *interquartile range (IQR) (whisker), and outliers (dots).

ten Varroa mites, varied significantly (GLMM, $p<0.001)$. Similarly, cells from which mites were removed and brood cells were recapped were significantly affected by the number of mites introduced (GLMM, $p<0.001$ ). The percentage of cell caps opened and brood and mite removed did not differ between different numbers of mites introduced (GLMM, $p>0.05$ ). In fact, for cell caps opened, the null model was the one with highest explanatory power according to the AIC (see model selection and simplification in Tab. S2). In all cases with a significant effect of the number of mites, the time point of introduction and the interaction term (number of mites $x$-time point) were removed from the models after stepwise removal (Tab. S2).

Post-hoc tests (Tukey HSD) were used to infer which pairwise differences for the factor number of cells singly introduced with mites (five, eight, or ten) were significant (Figure 2). Our results indicated that for the untouched cells, there was significant difference between five vs eight cells singly infested with mites $(p<0.001)$ and five vs ten cells singly infested with mites $(p<0.001)$, while there was no significant trend for eight vs ten cells singly infested with mites $(p=0.07)$
(Figure 2a). The percentage of introduced mites removed but brood still present and recapped showed significant difference when five vs eight $(p<0.001)$ and five vs ten singly infested cells $(p<0.001)$ were considered, but no significant difference between eight vs ten singly infested cells $(p=0.435)$ (Figure 2d). Overall, the effect sizes were considerably large with $r^{2}=0.662$ for untouched cells and $r^{2}=0.333$ for mite removed and cell recapped.

In this study, A. m . scutellata bees responded towards artificially infested brood cells within a relatively short period. Maximal rates of manipulation were already recorded after $72 \mathrm{~h}$. This result confirms previous observations that bees usually react to Varroa-infested brood cells within a few days following infestation (Aumeier et al. 2000; Guerra Jr. et al. 2000; Aumeier and Rosenkranz 2001; Harris 2007). The live mites were removed in 178 of 690 (25.8\%) manipulated brood cells, and the cells had been properly recapped by the VSH bees, while only in a minor fraction of cases, 43 of $690(6 \%)$ cells were found completely emptied (BR) with no recordings of the other hygienic behavioral components (UC, CO, MR). 

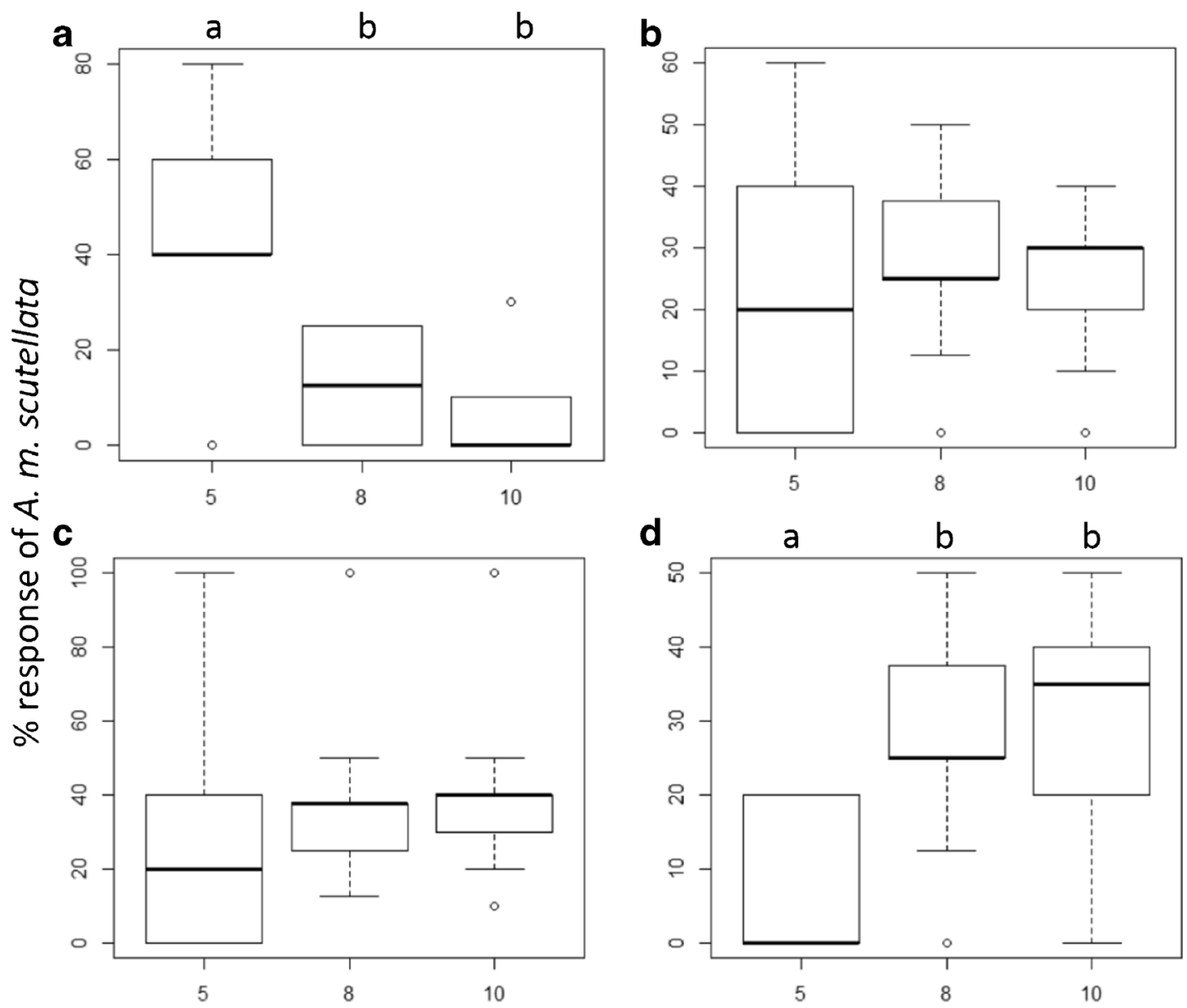

Number of mites introduced

Figure 2. Percentage response of Apis mellifera scutellata to manipulated cells introduced with mites. a untouched cells $(n=110)$, $\mathbf{b}$ cells cap opened $(n=171)$, $\mathbf{c}$ brood and mite were removed $(n=231)$, $\mathbf{d}$ mite was removed but brood is still present and recapped ( $n=178$ ). Vector number of mites were significant for a, $\mathbf{c}$, and $\mathbf{d}$ (GLMM, $p<$ 0.001 ) and $\mathbf{b}$ was not significant (GLMM, $p>0.05$ ). Different letters in a and $\mathbf{d}$ indicate significant difference in Tukey post-hoc test. Shown is the median (line), first and third quartile (box), first and third incl. 1.5 *IQR (whisker), and outliers (dots).

\section{DISCUSSION}

Our study strongly indicates a more complex combination of Varroa-specific hygienic behavioral components in Apis mellifera scutellata colonies. Of the 690 brood cells (69 brood cells per colony) artificially introduced with mites, Apis mellifera scutellata bees were able to uncap, remove the mite and recap $25.8 \%$ of the brood cells (178 of 690 manipulated cells) and removed $33.5 \%$ of the infested pupae together with the mite (231 of 690 manipulated cells). This is comparable to previous studies that compared to Africanized bees and Carniolan bees reported that $10 \%$ of the infested pupae had been removed by VSH bees and in about one third of the manipulated cells the mite had been removed (Aumeier et al. 2000; Aumeier and Rosenkranz 2001). Aumeier and Rosenkranz (2001) further noted that Africanized bees were able to express hygienic behavior of between 24 and $44 \%$ 
(summing up all behavioral components) in cells artificially infested with dead mites. Guerra Jr. et al. (2000) documented that Africanized bees expressed hygienic behavior with a mean of $51 \%$ of the total artificially miteinfested brood in experiments that compared them with Italian honey bees. Panziera et al. (2017) also reported that VSH bees are able to remove up to $40 \%$ of mite infested brood cells in naturally selected Varroa resistance honey bees of European origin. Our results indicated that the percentage of artificially infested brood cells which were subject to Varroa-specific hygienic behavior (CO, BR, MR) was $84.1 \%$ (580 cells out of 690 manipulated cells with mites) when at least cell opening is considered. In $59.3 \%$ of all cases (409 of 690 cells), the mite was removed (BR, MR). However, there was a strong effect of the number of mites introduced, with treatments where ten mites were singly introduced in a patch of closely neighboring brood cells showing highest levels of uncapping $(95.7 \%)$ and removal $(70.3 \%)$. These findings suggest that there is higher expression of Varroa-specific hygienic behavior in Apis mellifera scutellata as compared to Africanized bees and strain of honey bees of European origin. However, the expression of hygienic behavior is strongly influenced by environmental factors (nectar flow and strength of honey bee colonies) and by the percentage of bees in the colony capable of performing the task (Momot and Rothenbuhler 1971; Arathi and Spivak 2001).

VSH behavior in our study was estimated in the first $72 \mathrm{~h}$ after introduction suggesting that it measures the ability to recognize and eliminate mites as such before (severe) damage to the pupae occurs. A study by Frey et al. (2013) revealed that within the first few hours after cell capping, honey bee worker larvae provide the signals for the activation of the Varroa reproduction and therefore increased chances of mites' removal during this period. Our study demonstrates that bees continuously seek to clean brood $24 \mathrm{~h}$ after cell capping, an indication that other factors are involved in eliciting VSH behavior. Though reproducing mites are removed at a higher rate by $\mathrm{VSH}$ bees leading to higher percentage of infertile mites (Harbo and Harris 2005), the high VSH behavior observed in our study was significantly contributed by mites' introduction in patches of closely neighboring brood cells. Furthermore, the studies of the American groups of Harbo and Spivak used selected lines of honey bees of European origin, while we have studied the behavior in a natural population of honey bees of African origin. The origin of bees might also explain differences in the mechanistic basis of VSH behavior.

Another environmental factor might be a form of adaptation of the colony in form of learning over time. This was not evident in our experiment, which was performed over a total time period of 4 months. The factor time never had an effect on the outcome of VSH behavior indicating that learning might not play any significant role. Presumably, workers perform the tasks of hygienic behavior only during a restricted time of their lifetime and hence, learning is not possible over longer time periods. Furthermore, a colony is genetically diverse hence, the activity of individual hygienic bees is not sufficient to meet the increased demand for task performance (Arathi et al. 2006). Studies have shown that olfaction plays a role in hygienic behavior (Masterman et al. 2000; Plettner et al. 2017) and that the origin of VSH behavior is at least partly related to shifts in antennal gene expression (Mondet et al. 2015), therefore, olfactory cues might have played a critical role in the expression of VSH behavior in this study. Worker bees may have detected the presence of different densities of mites in brood cells using these cues other than the previously known fertility signals and the response to these chemical signals seem to be additive as highest removal rates were observed for eight or ten mites compared to five mites singly introduced in closely neighboring brood cells.

Moreover, our results indicate that the expression of Varroa-specific hygienic behavior is strongly dependent on the density of mites at a certain region/patch of neighboring brood cells infesting the colony. We observed a strong and highly significant effect of the number of mites that were introduced for the total number of cells that were left untouched by the bees and for the 
number of cells which were opened, mite was removed, and the cell was recapped. The two variables were shown to be strongly dependent on the number of mites introduced, an effect that was not seen for the number of cells which were opened only and from which brood and mite were removed. The strong effect of the number of mites on the expression of hygienic behavior is an indicator for the involvement of chemicals in the recognition of mites infesting cells (Nazzi and Le Conte 2016; Plettner et al. 2017). VSH bees were more responsive to manipulated brood cells singly introduced with ten mites in a patch of neighboring brood cells as compared to those singly introduced with five mites in a patch of neighboring brood cells probably because the chemical signals that triggers hygienic behavior are less concentrated and harder to detect in brood with low infestation rate (Masterman et al. 2001; Martin et al. 2002). However, it might be that hygienic bees that uncap and remove mites have a specific internal threshold (Theraulaz et al. 1998) for performing that task and under low infestation levels only a minority, those with a low threshold for the odorant cue performs the task. With increasing numbers of mites more workers will become involved, as those having a higher threshold will also perform the task. Though the experiment was done using low mite infestations, VSH behavior plays an important role in Varroa resistance at the level of the colony as this behavior might get significant at high mite infestation levels, after a brood less period (the starting small capped brood cluster in a colony), and just before a new brood less period (the last small concentration of capped brood). Furthermore, the placement of controls on the other sides of the brood combs may have had an effect in our study. However, the difference in VSH behavior among the different densities indicates that the bees clearly exhibited VSH behavior. Though removal of mite infested brood has been confirmed in most research studies (reviewed in Boecking and Spivak 1999), it is not clear whether the mechanisms for the detection of dead brood are the same as for the detection of mite-infested cells and whether there is sufficient correlation between "killed brood" and "removal of mite infested brood cells" (Boecking et al. 2000). Despite this, "Mite-only removal" behavior can be considered an adaptive behavioral mechanism that reflects the specific response of hygienic bees to mite-infested brood cells leading to reduced fitness of the Varroa mite.

In this study, we confirmed that Apis mellifera scutellata bees are able to remove introduced mites and recap the brood cells; therefore, Varroa specific hygienic behavior is triggered by high infestation rates in patches of closely neighboring brood cells. Our recommendation is that future research should focus on VSH behavior between subspecies of African bees and European bees.

\section{ACKNOWLEDGEMENTS}

We would like to thank bee-keeping technicians James Nganga Kimani, Joseph Kilonzo Wambua, and Newton Musungu Ngui who assisted with the sample collection and hygienic behavior assays. Thanks and acknowledgement to Dr. Daisy Salifu, the biostatistician of International Centre of Insect Physiology and Ecology for providing advice during planning of the experiment. We gratefully acknowledge the financial support for this research by the following organizations and agencies: International Fund for Agricultural Development (IFAD-2000000282); UK Aid from the UK Government; Swedish International Development Cooperation Agency (Sida); the Swiss Agency for Development and Cooperation (SDC); and the Kenyan Government.

\section{AUTHORS' CONTRIBUTION}

SKC, JPM, and EM conceived research and designed experiments; SKC performed experiments; SKC and HMGL analyzed data and wrote the manuscript; SKC, HMGL, and RKG revised the manuscript. All authors read and approved the final manuscript.

\section{COMPLIANCE WITH ETHICAL STANDARDS}

Conflict of interest The authors declare that they have no conflict of interest.

Disclaimer The views expressed herein do not necessarily reflect the official opinion of the donors. 


\section{OPEN ACCESS}

This article is distributed under the terms of the Creative Commons Attribution 4.0 International License (http://creativecommons.org/licenses/by/4.0/), which permits unrestricted use, distribution, and reproduction in any medium, provided you give appropriate credit to the original author(s) and the source, provide a link to the Creative Commons license, and indicate if changes were made.

Comportement hygiénique Varroa -spécifique de Apis mellifera scutellata au Kenya

Apis mellifera scutellata / cellules de couvain artificiellement infestées / comportement hygiénique spécifique au Varroa

Varroa-spezifisches Hygieneverhalten von Apis mellifera scutellata in Kenya

Apis mellifera scutellata / künstlich infizierte Brutzellen / Varroa -spezifisches Hygieneverhalten

\section{REFERENCES}

Aizen, M. A., Harder, L. D. (2009) The Global Stock of Domesticated Honey Bees Is Growing Slower Than Agricultural Demand for Pollination. Current Biology $19,1-4$

Arathi, H. S., Spivak, M. (2001) Influence of colony genotypic composition on the performance of hygienic behaviour in the honeybee, Apis mellifera. Animal Behaviour 62, 57-66.

Arathi, H. S., Burns, I., Spivak, M. (2000) Ethology of Hygienic Behaviour in the Honey Bee Apis mellifera L. (Hymenoptera: Apidae): Behavioural repertoire of Hygienic bees. Ethology 106(4), 365-379

Arathi, H. S., Ho, G., Spivak, M. (2006) Inefficient task partitioning among nonhygienic honey bees (Apis mellifera L.) and implications for disease transmission. Animal Behaviour 72(2), 431-438

Aumeier, P., Rosenkranz, P. (2001) Scent or movement of Varroa destructor mites does not elicit hygienic behaviour by Africanized and Carniolan honey bees. Apidologie. 32, 253-263.

Aumeier, P., Rosenkranz, P., Gonçalves, L. S. (2000) A comparison of the hygienic response of Africanized and European (Apis mellifera carnica) honey bees to Varroa -infested brood in tropical Brazil. Genetics and Molecular Biology 23, 787-791
Boecking, O., Spivak, M. (1999) Behavioral defenses of honey bees against Varroa jacobsoni Oud. Apidologie $30,141-158$

Boecking, O., K. Bienefeld, W. Drescher. (2000) Heritability of the Varroa-specific hygienic behaviour in honey bees (Hymenoptera: Apidae), J. Anim. Breed. Genet, $117,417-424$

Dietemann, V., Nazzi, F., Martin, S. J., Anderson, D. L., Locke, B., et al . (2013). Standard methods for Varroa research. In: Dietemann, V., Ellis, J. D. and Neumann, $\mathrm{P}$ (eds). The COLOSS BEEBOOK, Volume II: Standard methods for Apis mellifera pest and pathogen research. Journal of Apicultural Research 52(1). DOI.org/10.3896/IBRA.1.52.1.09

Donze, G., Herrmann, M., Bachofen, B., Guerin, P. M. (1996) Effect of mating frequency and brood cell infestation rate on the reproductive success of the honeybee parasite Varroa jacobsoni. Journal of Ecological Entomology 21, 17-26

Evans, J. D., Spivak, M. (2010) Socialized medicine: individual and communal disease barriers in honey bees. Journal of Invertebrate Pathology 103, S62-S72

Frazier, M., Muli, E., Conklin, T., Schmehl, D., Torto, B., et al. (2009) A scientific note on Varroa destructor found in East Africa; threat or opportunity? Apidologie $41,463-465$

Frey, E., Odemer, R., Blum, T., Rosenkranz, P. (2013) Activation and interruption of the reproduction of Varroa destructor is triggered by host signals (Apis mellifera). Journal of invertebrate pathology 113(1), 56-62

Fries, I., Raina, S. (2003) American foulbrood and African honey bees (Hymenoptera: Apidae). Journal of Economic Entomology 96(6), 1641-6

Fries, I., Camazine, S., Sneyd, J. (1994) Population Dynamics of Varroa Jacobsoni: A Model and a Review. Bee World 75(1), 5-28

Garedew, A., Schmolz, E., Lamprecht, I. (2004) The energy and nutritional demand of the parasitic life of the mite Varroa destructor: Apidologie 35 419-430

Gramacho, K., Gonçalves, L. (2009) Sequential hygienic behavior in Carniolan honey bees (Apis mellifera carnica ). Journal of Genetics and Molecular Research 8(82), 655-663

Guerra Jr., J. C. V., Gonçalves, L. S., DeJong, D. (2000) Africanized honey bees (Apis mellifera L.) are more efficient at removing worker brood artificially infested with the parasitic mite Varroa jacobsoni Oudemans than are Italian bees or Italian/Africanized hybrids. Genetics and Molecular Biology 23(1), 89-92

Harbo, J. R., Harris, J. W. (2005) Suppressed mite reproduction explained by the behaviour of adult bees. Journal of Apicultural Research 44(1), 21-23.

Harris, J. W. (2007) Bees with Varroa Sensitive Hygiene preferentially remove mite infested pupae aged $\leq$ five days' post capping. Journal of Apicultural Research 46(3), 134-139

Harris, J. W., Danka, R. G., Villa, J. D. (2010) Honey Bees (Hymenoptera: Apidae) With the Trait of Varroa Sensitive Hygiene Remove Brood With All Reproductive 
Stages of Varroa Mites (Mesostigmata: Varroidae). Annals of the Entomological Society of America 103(2), 146-152

Ibrahim, A., Spivak, M. (2006) The relationship between hygienic behavior and suppression of mite reproduction as honey bee (Apis mellifera) mechanisms of resistance to Varroa destructor. Apidologie 37(1), 31-40

Ifantidis, M. D. (1983) Ontogenesis of the mite Varroa jacobsoni in worker and drone honey bee brood cells. Journal of Apicultural Research 22, 200-206

Kinati, T., Tolemariam, T., Debele, K., Tolosa, T. (2012) Opportunities and challenges of honey production in Gomma district of Jimma zone, South-west Ethiopia. Journal of Agricultural Extension and Rural Development 4(4), 85-91

Lattorff, H. M. G., Buchholz, J., Fries, I., Moritz, R. F. A (2015) A selective sweep in a Varroa destructor resistant honey bee (Apis mellifera) population. Infect. Genet. Evol. 31, 169-176

Locke, B. (2016) Inheritance of reduced Varroa mite reproductive success in reciprocal crosses of mite-resistant and mite-susceptible honey bees (Apis mellifera). Apidologie 47, 583-588

Macedo, P. A., Wu, J., Ellis, M. D. (2002) Using inert dusts to detect and assess Varroa infestations in honey bee colonies. Journal of Apicultural Research 41(1-2), 3-7

Martin, C., Provost, E., Bagneres, A. G., Roux, M., Clement, J. L., et al . (2002) Potential mechanism for detection by Apis mellifera of the parasitic mite Varroa destructor inside sealed brood cells. Physiological Entomology 27(3), 175-188

Martin, S. J., Schroeder, D. C., Brettell, L., Highfield, A. C., Budge G. C., et al. (2012) Global viral landscape altered by a parasitic mite. Science 336, 1304-1306

Masterman, R., Smith, B. H., Spivak, M. (2000) Brood odor discrimination abilities in hygienic honey bees (Apis mellifera L.) using proboscis extension reflex conditioning. J. Insect. Behav. 13, 87-101

Masterman, R., Ross, R., Mesce, K., Spivak, M. (2001) Olfactory and behavioral response thresholds to odors of diseased brood differ between hygienic and nonhygienic honey bees (Apis mellifera L.). J. Comp. Physiol. 187, 441-452

Momot, J. P., Rothenbuhler, W. C. (1971) Behaviour genetics of nest cleaning in honey bees: VI. Interactions of age and genotype of bees, and nectar flow. Journal of Apicultural Research. 10, 11-12

Mondet, F., Alaux, C., Severac, D., Rohmer, M., Mercer, A. R., et al . (2015) Antennae hold a key to Varroa-sensitive hygiene behaviour in honey bees. Sci Rep. 5, 10454

Moritz, R. F. A. (1985) Heritability of the postcapping stage in Apis mellifera and its relation to varroatosis resistance. Journal of Heredity 76(4), 267-270

Moritz, R. F. A. (1988) A reevaluation of the two-locus model for hygienic behavior in honey bees (Apis mellifera L.). Journal of Heredity 79, 257-262

Moritz, R. F. A., Erler, S. (2016) Lost colonies found in a data mine: Global honey trade but not pests or pesticides as a major cause of regional honey bee "Agriculture, Ecosystems and Environment," 216(October 2015), 44-50

Muli, E., Patch, H., Frazier, M., Frazier, J., Torto, B., et al . (2014) Evaluation of the distribution and impacts of parasites, pathogens, and pesticides on honey bee (Apis mellifera ) populations in East Africa. PLoS One 9(4), e94459

Nazzi, F., Le Conte, Y. (2016) Ecology of Varroa destructor, the Major Ectoparasite of the Western Honey Bee, Apis mellifera. Annu. Rev. Entomol. 61:417-32

Neumann, P., Carreck, N. L. (2010) Honey bee colony losses. Journal of Apicultural Research, 49(1), 1-6

Newton, D. C., Ostasiewski, N. J. A. (1986) A simplified bioassay for behavioral resistance to American Foulbrood in honey bees (Apis mellifera L.). American Bee Journal 126, 278-281

Nganso, B. T., Fombong, A. T., Yusuf, A. A., Pirk, C. W. W., Stuhl, C., et al. (2017) Hygienic and grooming behaviors in African and European honeybees-New damage categories in Varroa destructor. PLoS One 12(6), e0179329

Oxley, P. R., Spivak, M., Oldroyd, B. P. (2010) Six quantitative trait loci influence task thresholds for hygienic behaviour in honey bees (Apis mellifera). Mol. Ecol. $19,1452-1461$

Paul Page, Lin, Z., Buawangpong, N., Zheng, H., Hu, F., et al. (2016) Social apoptosis in honey bee superorganisms. Nature Publishing Group, DOI.org/10.1038/ srep2 7210

Palacio, M. A., Rodriguez, E., Goncalves, L., Bedascarrasbure, E., Spivak, M. (2010) Hygienic behaviors of honey bees in response to brood experimentally pin-killed or infected with Ascosphaera apis. Apidologie, DOI: /https://doi. org/10.1051/apido/2010022

Panziera, D., van Langevelde, F., Blackquiere, T. (2017) Varroa sensitive hygiene contributes to naturally selected varroa resistance innhoney bees. Journal of Apicultural Research 56(5), 635-642

Peng, Y.S., Fang, Y., Xu, S., Ge, L. (1987) The resistance mechanism of the Asian honey bee, Apis cerana Fabr to an ectoparasitic mite, Varroa jacobsoni Oudemans. Journal of Invertebrate Pathology 49(1), 54-60

Pereira, R., Morais, M., Francoy, T., Gonçalves, L. (2013) Hygienic Behavior of Africanized Honey Bees Apis mellifera Directed towards Brood in Old and New Combs during Diurnal and Nocturnal Periods. Insects 4(4), 521-532

Plettner, E., Eliash, N, Singh, N. K., Pinnelli, G. R, Soroker, V. (2017) The chemical ecology of host-parasite interaction as a target of Varroa destructor control agents. Apidologie 48, 78-92

Potts, S. G., Biesmeijer, J. C., Kremen, C., Neumann, P., Schweiger, O., et al . (2010) Global pollinator declines: trends, impacts and drivers. Trends Ecol. Evol 25 (6), 345-353

R Core Team. (2016) A language and environment for statistical computing. R Foundation for Statistical Computing, Vienna 
Rath, W. (1999) Co-adaptation of Apis cerana Fabr. and Varroa jacobsoni Oud. Apidologie, 30(3), 97-110

Rosenkranz, P., Aumeier, P., Ziegelmann, B. (2010) Biology and control of Varroa destructor. Journal of Invertebrate Pathology 103, S96-S119

Rothenbuhler, W. C. (1964) Behaviour genetics of nest cleaning in honey bees. I. Responses of four inbred lines to disease-killed brood. Anim. Behav. 12:578583

Strauss, U., Human, H., Gauthier, L., Crewe, R. M., Dietemann, V., et al. (2013) Seasonal prevalence of pathogens and parasites in the savannah honey bee (Apis mellifera scutellata). Journal of Invertebrate Pathology 114(1), 45-52

Theraulaz, G., Bonabeau, E., Deneubourg, J. L. (1998) Response threshold reinforcements and division of labour in insect societies. Proceedings of the Royal Society B 265 (1393), 327-332
Vandame, R., Morand, S., Colin, M. E., Belzunces, L. P. (2002) Parasitism in the social bee Apis mellifera: quantifying costs and benefits of behavioral resistance to Varroa destructor mites. Apidologie 33, 433-446

Vanengelsdorp, D., Hayes, J., Underwood, R. M., Pettis., J. (2008) A survey of honey bee colony losses in the U.S., Fall 2007 to Spring 2008. PLoS ONE 3(12) e4071

Villa, J. D., Danka, R. G., Harris, J. W. (2009) Simplified methods of evaluating colonies for levels of Varroa Sensitive Hygiene (VSH). Journal of Apicultural Research and Bee World 48(3), 162-167

Wilfert, L., Long, G., Leggett, H. C., Schmid-Hempel, P., Butlin, R., et al. (2016) Deformed wing virus is a recent global epidemic in honeybees driven by Varroa mites. Science 351, 594-597

Xonis, C., Thrasyvoulou, A., Taj, H. F. E. (2015) Variability of hygienic behavior in bee Apis mellifera macedonica. Bulgarian Journal of Agricultural Science 21(3), 674-679 